\title{
INVESTMENT ATTRACTIVENESS OF STATE COMPANIES FOR RESPONSIBLE INVESTMENT: THEORETICAL ASPECT AND APPLIED METHODS
}

\author{
Yelnikova Y. V. \\ Sumy State University \\ Ukraine, 40000, Rimsky-Korsakov str., 2, Sumy, Sumy region \\ yelnikovad@gmail.com \\ ORCID 0000-0002-8478-4716
}

Key words:

investment attractiveness of state companies, responsible investments, evaluation, investment environment.
The article deals with the formation of theoretical concepts and approaches to the identification of state-owned companies as subjects of responsible investment in the context of strengthening their investment attractiveness. In the course of this study, it was determined that among Ukrainian scientists, studies of state-owned companies in the context of their financial efficiency, investment attractiveness for VI and activities in the field of sustainable development are only becoming more widespread. Only some practices of responsible activity of companies, mostly private, are covered. It is proved that with the growing share of stateowned companies among the most influential corporations in the world there is an urgent question of assessing their investment attractiveness based not only on traditional indicators of financial efficiency, but also the ability to repeat value for society on responsible principles embodied in the ESG criteria, indicators. A number of indicators and methods for determining the investment attractiveness of the company are considered. The study found that the mobilization of investment resources, its allocation to infrastructure projects, taking into account the ESG criteria through state-owned enterprises creates the foundations for overall economic growth, not only in targeted sectors of strategic importance, where investments are directed. The participation of state-owned enterprises in the investment support of new sectors of the economy or those in need of restructuring may be an alternative to the introduction of special tax regimes.

\section{ІНВЕСТИЦІЙНА ПРИВАБЛИВІСТЬ ДЕРЖАВНИХ КОМПАНІЙ ДЛЯ ЗДІЙСНЕННЯ ВІДПОВІДАЛЬНИХ ІНВЕСТИЦІЙ: ТЕОРЕТИЧНИЙ АСПЕКТ ТА ПРИКЛАДНІ МЕТОДИКИ}

\author{
Сльнікова Ю. В. \\ Сумський державний університет \\ Україна, 40000, вул. Римського-Корсакова, 2, м. Суми, Сумська область
}

\section{Ключові слова:}

інвестиційна привабливість державних компаній, відповідальні інвестиції, оцінка, інвестиційне середовище.
У статті проведено формування теоретичних концептів та підходів до ідентифікації державних компаній як суб'єктів відповідального інвестування у контексті посилення їх інвестиційної привабливості. В ході даного дослідження було визначено, що серед українських вчених дослідження державних компаній у контексті їх фінансової ефективності, інвестиційної привабливості для діяльності у сфері сталого розвитку лише набувають популярності. Висвітлені лише окремі практики відповідальної діяльності компаній, в основному приватних. Доведено, що в умовах зростання частки державних компаній серед найбільш впливових корпорацій світу постає нагальне питання оцінювання їх інвестиційної привабливості виходячи не лише 3 традиційних індикаторів фінансової ефективності, але й здатності створювати цінність для суспільства на відповідальних засадах, що втілена в ESG - критеріях та відповідним їм індикаторам. Розглянуто ряд індикаторів та методик щодо визначення інвестиційної привабливості компанії. У ході дослідження виявлено, що мобілізація інвестиційних ресурсів, його алокація в інфраструктурні проекти, 3 урахуванням ESG - критеріїв через державні підприємства створює підвалини для загального економічного піднесення, не лише у таргетованих секторах стратегічного значення, куди спрямовуються інвестиції. Участь державних підприємств у інвестиційній підтримці нових галузей економіки чи тих, які потребують реструктуризації, може стати альтернативою запровадження спеціальних податкових режимів.

\section{Formulation of the problem}

State-owned companies (state-owned enterprises) are gradually increasing their position in the world rankings of the largest companies and, given the subject of the study, they need more attention as leaders of sustainable development values and key entities of state investment policy (SIP) of a responsible type.

Thus, the share of state-owned companies in the Fortune Global 500 is growing extremely fast. In 2005, it 
accounted for $9 \%$ of the total number of companies, in 2014 it was $23 \%$ (primarily due to Chinese state-owned enterprises) [1]. In 2019, the share of only Chinese companies reached $26 \%$ [2]. At the country level, stateowned companies can take quite significant shares -60 $\%$ of companies in China, $40 \%$ of companies in Russia, $20 \%$ in Brazil. Along with the world's largest private corporations, the role of state-owned companies in financing the Sustainable Development Goals by instruments of responsible investment (RI) is growing not only due to their growing role in global financial and economic processes but also due to their immanent focus on achieving strategic socio-environmental and economic goals. From this point of view, the study of investment attractiveness of state-owned companies for the RI implementation becomes especially important, because they can be drivers of investment resources growth to provide countries progress, including Ukraine, on the path to sustainable development.

\section{Analysis of recent studies and publications}

The studies of the investment attractiveness of stateowned companies for the RI implementation are carried out by both foreign and domestic scientists. Thus, P. Kowalskii, M. Bügei, M. Sztajerowska, M. Egelandi (2013) [5], P. Hsu, P. Matos, H. Liang (2018) [3] suggest that state-owned companies are important in RI within the SIP. The researchers used complex datasets of Thomson Reuters' ASSET4 environmental scores, MSCI ESG Intangible Value Assessment and Sustainalytics ESG Ratings for 2004-2014 for investigating listed stateowned companies in 44 countries. They found that stateowned companies with higher scores of environmental activities (involved in reducing greenhouse gas emissions and the use of natural resources, the spread of environmentally friendly innovations), have higher financial efficiency.

Studies of state-owned companies in the context of their financial efficiency, investment attractiveness for RI and activities in the field of sustainable development are carried out more intensive in Ukraine. There is a little number of companies that provide practices of responsible activities. They are mostly private.

T. Romanyok investigated the private companies in the context of their investment attractiveness for RI. The author developed the methodology for making a comprehensive assessment of potential RI objects. It includes industry ranking of Ukrainian business priorities, development of diagnostic parameters of economic, environmental, social, ethical, informational, governance and innovative criteria for the assessment of companies with an aim of whether include them in the RI portfolio or not.

In addition, it was paid attention to the study of companies according to their sectoral specifics (metallurgy, electricity, food, oil and gas, pharmaceuticals, agricultural and retail sectors). However, the form of companies' ownership was not taken into account. The study was made mostly for a very limited number of private companies - 14 (domestic and foreign) from 7 sectors [11].

D. Leus developed methodological principles for assessing the investment attractiveness of the securities' issuer as an object of SIP and the formation of their SIP strategy, by investing in companies with a high level of correlation between CSR and revenue. It was proposed to evaluate such a connection on the basis of $\rho$ Spearman's non-parametric method. It allowed the author to make an adequate mathematical interpretation of the obtained results. Among the 37 companies, state-owned companies were also not represented [10].

\section{The purpose of the article}

The objective of the article is to form theoretical concepts and approaches to the identification of stateowned companies as subjects of RI in the context of strengthening of their investment attractiveness.

\section{The main research results}

Despite some similarities in trends, threats and opportunities of private and state-owned companies, there is a fundamental difference between them. It is mission, vision, and strategy. The immanent characteristic of state-owned companies is their focus on population well-being, socio-economic or socioenvironmental effect (values). At the same time, achieving high financial indicators is not constant for such enterprises. RI has a rather similar characteristic. State-owned companies as SIP entities have a dualistic position. On the one hand, with its investment support of such companies within the SIP, the state can force the development of strategically important industries and achieve the necessary socio-environmental and economic targets. On the other hand, the state-owned companies as SIP subjects must conduct both their investment policy and all activities on a responsible basis.

With the growing share of state-owned companies among the world's most influential corporations, there is an urgent need to assess their investment attractiveness based not only on traditional indicators of financial efficiency but also the ability to create value for society on a responsible basis, embodied in ESG criteria.

Therefore, in the study [2] it is discussed the necessity for a new adjusted map of Key Performance Indicators (KPIs) for state-owned companies. It comprehensively illustrates their activities, including indicators of companies' impact on social, human, innovative and natural capital.

At the same time, a number of criteria have been developed to identify new types of state-owned companies among other companies, including in OECD studies:

level of state regulation of companies (national, regional, local);

the character of state participation in the company establishment (full, minority, the majority);

the company's position in the hierarchy of public administration;

the purpose of creating a state-owned company; company status in the privatization process;

the state as a stakeholder in the operating of pension funds, asset management funds, institutions that finance the development [8].

For the study, we use the understanding of state-owned companies according to the OECD approach. Based on 
this, the state has significant control in companies through full, minority or majority participation, regardless of the level of public authorities.

In 2013-2016 in developed countries, including European (Denmark, Spain, the Netherlands, Finland and Sweden) [6] investment activities of state-owned companies were regulated in the context of focusing on the sustainable development values and strengthening of their immanent social responsibility by regulating the non-financial information disclosure on ESG criteria. In 2017-2020 the developed countries were replaced by developing countries with a dominant sector of state-owned companies. In particular, [1] in Indonesia, State-Owned Enterprise Regulation (2017) regarding companies' achievements in SDGs disclosure in annual reports was adopted in 2017. A centralized approach to non-financial information disclosure by the above-mentioned stateowned companies is being actively implemented in China too.

The management report was developed for large and medium-sized companies in Ukraine in 2017. It is based on the Law of Ukraine "On Accounting and Financial Reporting in Ukraine". Additionally, the implementation of the Directive also applies to state-owned companies. Contrary to private companies, state-owned companies should create exemplary practices of supporting the SDGs, implementation of CSR activities and information disclosure, taking into account the immanent origin of accountability and responsibility to society.

The OECD and the World Bank [8, 10] highlight many specific characteristics of state-owned companies, which the author supplemented in terms of their participation in investment processes of a new type of financial system focused on financing the sustainable development based on ESG criteria. They include:

ensuring the well-being of the population and future generations (state defense, education, health care) mainly social criteria;

forming of own investment resources and efficient use of state investment resources in certain sectors (mainly state monopolies) - economic and governance criteria;

investment support of new but low-profit sectors of the economy or emerging sectors, sectors that are in a recession and need the restructuration but have important socio-economic or environmental significance - social, environmental and economic criteria,

improvement of labor relations and social security in strategically important sectors of the economy - mainly social criteria;

restrictions on private and foreign economic control in strategically important sectors of the economy economic and governance criteria;

These characteristics are vital for state-owned companies as for the SIP entities because primarily state directs their investment activities to eliminate market failures, fulfill social needs and decrease the pressure on the environment. For all that, the mobilization of investment resources, its allocation to infrastructure projects with taking into account the ESG criteria through state-owned enterprises creates the base for general economic growth, not only in primary sectors, where investments are directed. The participation of state-owned enterprises in the investment support of new sectors of the economy or those that need the restructuration may become an alternative to the establishment of special tax regimes.

For this reason, we can conclude that state-owned companies should be an outstanding example for private companies in using the best governance and investment practices to offset natural risks and capitalize opportunities in the environment to generate long-term value for stakeholders. Moreover, in developing countries, state-owned companies can be used to mitigate environmental risks in weak institutional conditions, as the effect of presence of such companies in the economic sector is the same as the establishment of environmental taxes.

In a previous study concerning the portfolio optimization of the traditional and responsible companies and the RI portfolio formation on the criteria of "risk-return", taking into account the Markowitz theory of portfolio optimization of state-owned companies were not represented [1]. But it was made an important conclusion that the investment portfolios of responsible companies have higher parameters (risk, return) than the portfolios of traditional companies. This conclusion allows us making assumptions about the importance of the responsible activity criterion to increase the companies' investment attractiveness, including state-owned with the same indicators of financial efficiency.

\section{Conclusions}

According to the research and analysis of the studies of scientists and leading organizations (OECD, World Bank), several characteristics of state-owned companies as RI entities were formed. Among these characteristics, the integration of the ESG criteria set into the companies' activities and increasing their transparency to overcome market externalities and ensure the population well-being should be considered as principal.

As a result, state-owned companies should develop a system of benchmarks for private companies regarding responsible governance and investment and the producing of long-term value for stakeholders. Nevertheless, the implementation of responsible activities is crucial to increase the investment attractiveness of companies with the same financial efficiency indicators. Given the fact that responsible activities have a positive impact on the companies' financial efficiency, including state-owned. Besides, it reduces risks and costs through more efficient resources usage and environmentally friendly technologies provides additional reputational and investment benefits. Its activation can enhance the investment attractiveness of these companies in Ukraine.

\section{References}

1. Carrots and Sticks. (2020). Sustainability reporting policy: Global trends in disclosure as the ESG agenda goes mainstream. Retrieved from https://www.carrotsandsticks.net/reportinginstruments/?status=Forthcoming\&status=Current 
2. Catalysts for public value creation? Retrieved from https://www.pwc.com/gx/en/psrc/publications/assets/pwcstate-owned-enterprise-psrc.pdf

3. Hsu, Po-Hsuan and Liang, Hao and Matos, Pedro, Leviathan Inc. and Corporate Environmental Engagement (2018). Darden Business School Working Paper No. 2960832. Retrieved from SSRN: https://ssrn.com/abstract=2960832 or http://dx.doi.org/10.2139/ssrn.2960832

4. It's China's World. Retrieved from https://fortune.com/longform/fortune-global-500-china-companies/

5. Kowalski, P. (2013). State-Owned Enterprises: Trade Effects and Policy Implications / P. Kowalski. OECD Trade Policy Papers, - No. 147. -OECD Publishing, Paris. Retrieved from https://doi.org/10.1787/5k4869ckqk71-en.

6. KPMG/GRI: Carrots and sticks - Sustainability reporting policies worldwide - today's best practice, tomorrow's trends. 2013. Retrieved from https://www.globalreporting.org/resourcelibrary/carrots-andsticks.pdf

7. Kwiatkowski G., Augustynowicz P. (2015). State-Owned Enterprises in the Global Economy - Analysis Based on Fortune Global 500 List / Retrieved from https://www.pwc.com/gx/en/psrc/publications/assets/pwc-stateowned-enterprise-psrc.pdf

8. OECD (2005). Comparative Report on Corporate Governance of State-owned Enterprises. Retrieved from https://www.oecd.org/corporate/guidelines-corporate-governance-soes.htm

9. Plastun A., Makarenko I., Yelnikova Y. and Bychenko D. (2019). Optimal investment portfolio selection from the largest Ukrainian companies: comparative study of conventional and responsible portfolios/ A. Plastun, I. Makarenko, Y. Yelnikova and D. Bychenko. - S.: Public and Municipal Finance. - №8(1), - P. 44-53. doi:10.21511/pmf.08(1).2019.04

10. The World Bank, (2006). Held by the Visible Hand - the Challenge of SOE Corporate Governance for Emerging Markets. Retrieved from https://documents.worldbank.org/en/publication/documentsreports/documentdetail/396071468158997475/held-by-the-visible-hand-the-challenge-of-state-owned-enterprisecorporate-governance-for-emerging-markets

11. Leus D. V. Portfel'ne investuvannya yak instrument finansovoho zabezpechennya staloho rozvytku ekonomiky Ukrayiny [Portfolio investment as a tool for financial support of sustainable development of Ukraine's economy]: Extended abstract of candidate's thesis. Sumy: SumSU 2014. - 24 P. [in Ukrainian].

12. Roman'ok T. V. Vidpovidal'ne investuvannya $\mathrm{v}$ transnatsional'nomu biznesi [Responsible investing in transnational business] : Extended abstract of candidate's thesis. Kiev - 2014.. - 22 P. [in Ukrainian]. 